\title{
An in vitro cytotoxicity of glufosfamide in HepG2 cells relative to its nonconjugated counterpart
}

\author{
Doaa E. Ahmed ${ }^{1}$, Fatma B. Rashidi² ${ }^{*}$, Heba K. Abdelhakim², Amr S. Mohamed ${ }^{2}$ and Hossam M. M. Arafa ${ }^{3}$
}

\begin{abstract}
Background: Glufosfamide ( $\beta$-D-glucosylisophosphoramide mustard, GLU) is an alkylating cytotoxic agent in which ifosforamide mustard (IPM) is glycosidically linked to the $\beta$-D-glucose molecule. GLU exerted its cytotoxic effect as a targeted chemotherapy. Although, its cytotoxic efficacy in a number of cell lines, there were no experimental or clinical data available on the oncolytic effect of oxazaphosphorine drugs in hepatocellular carcinoma. Therefore, the main objective of the current study is to assess the cytotoxic potential of GLU for the first time in the hepatocellular carcinoma HepG2 cell line model.

Methods: Cytotoxicity was assayed by the MTT method, and half-maximal inhibitory concentration $\left(\mathrm{IC}_{50}\right)$ was calculated. Flow cytometric analysis of apoptosis frequencies was measured by using Annexin V/PI double stain, an immunocytochemical assay of caspase-9, visualization of caspase-3, and Bcl2 gene expression were undertaken as apoptotic markers. Mitochondrial membrane potential was measured using the potentiometric dye; JC-1, as a clue for early apoptosis as well as ATP production, was measured by the luciferase-chemiluminescence assay.

Results: Glufosfamide induced cytotoxicity in $\mathrm{HepG} 2$ cells in a concentration- and time-dependent manner. The $\mathrm{IC}_{50}$ values for glufosfamide were significantly lower compared to ifosfamide. The frequency of apoptosis was much higher for glufosfamide than that of ifosfamide. The contents of caspase- 9 and caspase-3 were elevated following exposure to GLU more than IFO. The anti-apoptotic BCl2 gene expression, the mitochondrial membrane potential, and the cellular ATP levels were significantly decreased than in case of ifosfamide.

Conclusions: The current study reported for the first time cytotoxicity activity of glufosfamide in HepG2 cells in vitro. The obtained results confirmed the higher oncolytic activity of glufosfamide than its aglycone ifosfamide. The generated data warrants further elucidations by in vivo study.
\end{abstract}

Keywords: Glufosfamide HepG2 cytotoxicity, Ifofosfamide (IFO), BCl-2, Caspase-9, Mitochondrial membrane potential

\section{Background}

Hepatocellular carcinoma (HCC) is a malignant tumor that arises from hepatocytes, the major cell type in the liver. It is the most common primary hepatic tumor and the fifth most common tumor worldwide. It has a high incidence in sub-Saharan Africa and Asia. About

\footnotetext{
*Correspondence: fatmabaiuomy@yahoo.com

${ }^{2}$ Biochemistry Lab.Department of Chemistry, Faculty of Science, Cairo University, Giza, Egypt

Full list of author information is available at the end of the article
}

46,000 new cases of hepatocellular carcinoma have been recorded to be diagnosed in sub-Saharan Africa each year, and age-standardized incidences of the tumor as high as 41.2/100,000 persons/year [1]. At the molecular level, HCC is a heterogeneous disease. It occurs in more than $80 \%$ of the cirrhotic liver, but the molecular pathways involved depend on the cause of cirrhosis. Liver carcinogenesis may last for decades, through progressive accumulation of different genetic alterations that eventually lead to malignant transformation. Thus, chronic liver 
injury initiates increased liver cell turnover, triggering oxidative DNA damage and inflammatory events. This leads to the formation of dysplastic and macro-regenerative nodules which are considered to be neoplastic nodules [2].

Systemic chemotherapy lacks a radical cure for HCC, and there is currently no standard treatment for patients with non-resectable HCC. Local ablation has shown strategies such as ethanol injection, radiofrequency, and cryotherapy can prolong survival in selected patients and prevent tumor progression while on a waiting list for transplantation. Innovative approaches such as targeting the non-transformed, less resistant, tumor-supporting endothelial cells may change this outcome [3].

Glufosfamide, a nitrogen mustard derivative, is an analog of oxazaphosphorine drugs. These belong to a class of bifunctional alkylating agents of potential chemotherapeutic activities towards varieties of human malignancies. Several new analogs of these drugs family including glufosfamide have been designed to increase therapeutic selectivity and reduce off-target toxicity, in comparison with their ascendants [4]. Glufosfamide (D-19575, $\beta$-D-glucose-isophosphoramide mustard, $ß$-D-Glc-IPM) is the next-generation glucose conjugate of ifosfamide; is a glucose conjugate of ifosfamide, in which isophosphoramide mustard, the bioactive alkylating metabolite of ifosfamide; and is covalently linked to $\beta$-D-glucose [5]. Glufosfamide has the potential to target tumor cells by serving as a substrate for such glucose transporters in the plasma membrane [6]. Together with the increased metabolic rate and glucose consumption of tumor cells, this targeting mechanism may contribute to the relative selectivity of the drug for tumor cells.

Another characteristic of glufosfamide is that, because of the absence of the oxazophosphorine ring in its structure, it does not release the urothelium irritant acrolein, which has been shown to induce hemorrhagic cystitis in individuals treated with IFO. Moreover, the amount of toxic chloroacetaldehyde generated metabolically after administration of D-19575 is markedly reduced compared with that generated after IFO administration. Preclinical pharmacokinetic analysis has revealed that glufosfamide is rapidly cleared by the kidney and has favorable tissue distribution and protein-binding profiles [7].

Although glufosfamide can trigger three forms of programmed cell death, namely, apoptosis, autophagy, and necrosis, the mechanisms of the action of glufosfamide have not yet been fully elucidated. Indeed, glufosfamide has proven apparent cytotoxicity in an array of tumor cell lines [4], and there was no data are available, however, on its oncolytic effect in hepatocellular carcinoma whether experimental or clinical.
Therefore, the objective of the current study aimed to assess and compare the cytotoxic potential of glufosfamide and its parent aglycone ifosfamide in a hepatocellular carcinoma cell line paradigm, namely, HepG2, in addition to shedding more light about the molecular mechanisms underlying the possible cytotoxic potential of both oxazophosphorine drugs.

\section{Methods}

\section{Chemicals and drugs}

GLU was obtained from Threshold Pharmaceuticals (South San Francisco, USA). Ifosfamide was obtained from Baxter Oncology GmbH (Weiterstadt, Germany). Dulbecco's modified Eagle's medium (DMEM): It was purchased from Life Technologies (CA. USA) and was used as a basal medium for supporting the growth of HepG2 cells. Fetal bovine serum (FBS): Sterile solution (10\%) was obtained from Sigma-Aldrich (St. Louis, MO, USA). L-Glutamine (200 mM) was obtained from SigmaAldrich (St. Louis, MO, USA). MTT (1-3(4, 5-dimethylthiazol-2-yl)-2,5-diphenyltetrazolium bromide) was prepared as $0.5 \mathrm{mg} / \mathrm{ml}$ solution and used for the evaluation of cytotoxicity. Trypan blue dye was obtained from Sigma-Aldrich (St. Louis, MO, USA). The dye was used to stain dead cells during the assessment of cytotoxicity. Trypsin/EDTA was purchased from Lonza Walkersville (Washington, USA). It was supplied as a solution of trypsin $(200 \mathrm{mg} / \mathrm{L})$ and EDTA $(17,000 \mathrm{U} / \mathrm{L})$. It was used in a concentration of $0.25 \%(\mathrm{w} / \mathrm{v})$ Trypsin $/ 0.53 \mathrm{mM}$ EDTA to detach HepG2 cells. Penicillin $(10,000 \mathrm{U} / \mathrm{mL}) /$ streptomycin $(10 \mathrm{mg} / \mathrm{mL})$ was obtained from SigmaAldrich (St. Louis, MO, USA) and used for sterilization of cell cultures. ANNEXIN V FITC/Pl apoptosis detection kit was purchased from Beckman Coulter GmbH (Krefeld, Germany) and used for flow cytometric detection of apoptosis. SYBR ${ }^{\circledR}$ Green PCR Master Mix and SYBR ${ }^{\circledR}$ Green RT-PCR Reagents Kit were purchased from Applied Biosystems (Life Technologies, CA, USA) and used to perform real-time PCR and direct detection and monitoring of PCR product. JC-1 mitochondrial membrane potential assay kit was purchased from Cayman Chemical Company (MI, USA) and used for the assessment of mitochondrial membrane potential in cultured HeG2 cells. Cell Titer-Glo Luminescent Cell Viability Assay kit, this kit was commercially obtained from Promega (CA, USA) and used for the cellular determination of ATP levels in HepG2 cells.

\section{Cell culture}

HepG2 (hepatocellular carcinoma cell line, ATCC Number HB-8065) was purchased from the Holding Company for Biological Products \& Vaccines (VACSERA, Agouza, Giza, Egypt). Cells were cultured in tissue culture 
flasks (75-cm2 surface area) using RPMI supplemented with $10 \%$ fetal bovine serum (FBS) as a growth culture medium and glutamine $(200 \mathrm{mM})$. Preliminary cultures and passages were made in the DMEM medium. The cell line was maintained according to the method earlier described by [8]. After discarding the culture medium, the cell layer was gently washed with sterile phosphate buffer saline (PBS), the cell layer was rinsed with $0.25 \%$ (w/v) Trypsin- $0.53 \mathrm{mM}$ EDTA solution to remove all traces of serum that contain trypsin inhibitor. About 2-3 ml of trypsin-EDTA solution was added to the flask and cells were observed under an inverted microscope until the cell layer was dispersed (usually within 5 to $15 \mathrm{~min}$ ). Cells that are difficult to detach may be placed at $37{ }^{\circ} \mathrm{C}$ in $\mathrm{CO}_{2}$ incubator to facilitate dispersal. Six to $8 \mathrm{ml}$ of complete growth medium was added to the cells to inhibit trypsin and then incubated in $5 \% \mathrm{CO}_{2}$ incubator at $37^{\circ} \mathrm{C}$. The medium renewal was done twice per week. Cell counting and viability check were performed using Dye Exclusion Technique. A cell number was calculated by counting the cells using a hemocytometer according to the method described by [9].

\section{Cytotoxicity assay}

Cytotoxicity of both glufosfamide and ifofosfamide was evaluated in cultured HepG2 cells. Experiments were designed to elucidate the cytotoxic potencies of both oxazophosphorine congeners on different time periods. Stock solutions were prepared by dissolving either drug in free medium. Drug concentration-response curves were assessed. Seeding was done at a density of 5000 cells/well in 96-well plates. Drug were used at concentrations of 10-1000 $\mu \mathrm{M}$. After cell conditioning and maintenance (as described in the "Material and methods" section), cells were treated with drug concentrations and incubated for different time intervals; 24, 48, and $72 \mathrm{~h}$. Cytotoxicity was assessed at the end of drug exposure using MTT assay as earlier described by Mosmann [10]. Following $24 \mathrm{~h}$ of cell plate incubation, the medium was removed and $200 \mu \mathrm{l}$ of medium containing different concentrations of either glufosfamide or ifosfamide (10$1000 \mu \mathrm{M})$ were added. After varying times of incubation the medium was removed, and for staining, $100 \mu \mathrm{l}$ of MTT solution in PBS was added to each well at final concentration of $0.5 \mathrm{mg} / \mathrm{ml}$ medium and incubated $1-5 \mathrm{~h}$. Then, media were dumped off and the plate were dried on paper towels, and formazan (MTT metabolic product) was made soluble in $200 \mu \mathrm{l}$ DMSO for 5 min on a shaker at $150 \mathrm{rpm}$. Absorbance was then measured using an ELISA plate reader at a test wavelength of $570 \mathrm{~nm}$ and a reference wavelength of $630 \mathrm{~nm}$ to obtain sample signal. Optical density should be directly correlated with cell quantity. Results were expressed as the relative percentage of absorbance compared to control. The cytotoxicity of each concentration was tested in triplicate and, and each experiment was repeated once to make an overall sample size of $n=6$. The half maximal inhibitory concentration $\left(\mathrm{IC}_{50}\right)$ was calculated using Graphpad Prism 5 software (San Diego, CA, USA). Drug interactions were analyzed by Calcusyn program version 2.1 (Biosoft, Cambridge, UK) based on the analytical method of Chou and Talalay [11].

\section{ANNEXIN V FITC/PI assessment of apoptosis}

Apoptosis was performed using ANNEXIN V FITC/Pl apoptosis assay kit (Krefeld, Germany) to quantify the number of cells undergoing apoptosis following tagging with annexin $\mathrm{v}$ protein. The tagged cells were visualized by flow cytometer. The apoptotic effects of the $\mathrm{IC}_{50}$ values (and some fractions) of both glufosfamide and ifofosfamide were addressed in the current study. After HepG2 cells conditioning and maintenance as in the "Materials and methods" Sect. (2.2.), they were treated with the test drug concentrations. The optimal incubation time before pulsation of the cells into the flowcytometer was selected from the cytotoxicity study to be $72 \mathrm{~h}$. Each experiment was done in triplicate and repeated once to give a sample size of $n=6$. The percentage of apoptosis (early and late) was calculated, and the mean values for each drug were computed.

\section{Human caspase- 9 measurement}

Apoptosis was further confirmed by the assessment of the content of human caspase- 9 in HepG2 cell lysates by ELISA kit obtained from Biovendor R \& D (Heidelberg, Germany) as per manufacturer instruction. After cell conditioning and maintenance, cells were lysed by lysis buffer and subjected to anti-human caspase- 9 antibody. Then, $\mathrm{IC}_{50}$ values of both glufosfamide and ifosfamide (fractions) were tested for their effects on human caspase-9 content. Experiments were done in triplicate and repeated one to a given sample size of $n=6$.

\section{$\mathrm{Bcl} 2$ and caspase-3 gene expression measurement}

HepG2 cells were prepared as mentioned above in the "Materials and methods" Sect. (2.2.), then the total RNA was extracted from cell lysate using SV total RNA isolation and purification system (Promega WI, USA), followed by reverse transcription. Then, the qPCR were carried out using gene-specific primers for caspase-3, Bcl2, and Beta actin, respectively, Fwd: 5' GTG TCT GGT CAT TTC CGA CTG A 3', Rev: 5'ATA CTC CAC AGC ACC TGG TTA T $3^{\prime}$ according to gene bank accession number: NM004346. Fwd: 5' GCA GGC GAC GAG TTT GAA CT 3' Rev: 5'GTG TCT GGT CAT TTC CGA CTG A $3^{\prime}$ according to gene bank 
accession number: NM138578 and Forward 5' TCT GGC ACC ACA CCT TCT ACA ATG 3' Reverse 5' AGC ACA GCC TGG ATA GCA ACG 3' accession number: XM_035085394.1. After calculation of the relative expression, $\mathrm{IC}_{50}$ values for both glufosfamide and ifosfamide were tested for the quantitative assessment of $\mathrm{Bcl} 2$ and caspase- 3 genes using real time PCR. Each experiment was done in triplicate and repeated once to a given sample size of $n=6$.

\section{Determination of the mitochondrial membrane potential in HepG2 cells}

This experiment was conducted to unravel the effects of both glufosfamide and ifosfamide on the mitochondrial membrane potential of HepG2 cells as a clue for early apoptosis. This was done using a potentiometric dye, JC- 1 , which is a membrane permeable dye widely used for determining mitochondrial membrane potential using fluorometer, flowcytometry, and fluorescent microscopy [12]. Mitochondrial membrane potential, $\Delta \psi \mathrm{m}$, is an important parameter of mitochondrial function used as an indicator of cell health. $\mathrm{IC}_{50}$ values obtained from the cytotoxicity study were used. Each experiment was done in triplicate and repeated once for a given sample size of $n=6$. Mitochondrial membrane potential was a function of the difference in excitation between the red J-aggregates and the green monomeric dye.

\section{ATP concentration measurement in HepG2 cells}

This test was performed as a mechanistic study to elucidate the effects of $\mathrm{IC}_{50}$ doses of glufosfamide and ifosfamide on cellular content of ATP using the luciferase-luminescence assay according to the method described by Mikirova et al. [13] using a commercial Cell Titer-GloLuminescent cell Viability Assay kit (Promega, USA). Luminescence relative units (LRU) were determined for each drug as count per seconds (CPS). Each dose was tested in triplicate and repeated once for a given sample size of $n=6$. Correlation analysis was further done to disclose the possible relationship between disruption of mitochondrial membrane potential and energy production.

\section{Statistical analysis}

Data are presented as mean $\pm \mathrm{SD}$; comparisons were carried out using one way analysis of variance (ANOVA) followed by Tukey-Kramer's test for post hoc analysis. Statistical significance was acceptable to a level of $P<0.001$. All statistical analysis was performed using Graph pad Prism 5 software (San Diego, CA, USA).

\section{Results \\ Effects of glufosfamide or ifosfamide on the viability of HepG2 cells}

To investigate the cytotoxic effect of glufosfamide or ifosfamide on HepG2, cell concentration response curves for each drug were assessed and compared. Both glufosfamide and ifosfamide showed enhanced cytotoxicity in HepG2 cells in a concentration- and time-dependent manner. The half-maximal inhibitory concentrations $\left(\mathrm{IC}_{50}\right)$ of glufosfamide were $112.32 \pm 8.5,83.23 \pm 5.6$, and $51.66 \pm 3.2$ following the corresponding incubation periods; 24, 48, and $72 \mathrm{~h}$, respectively (Table 1 and Fig. 1a). It was apparent that the optimal time period was at $72 \mathrm{~h}$ followed by $48 \mathrm{~h}$ and $24 \mathrm{~h}$. The $\mathrm{IC}_{50}$ of ifosfamide were $133 \pm 8.9,125 \pm 11.2$, and $100.2 \pm 7.6$ following the respective incubation periods; 24,48 , and $72 \mathrm{~h}$, respectively (Table 1 and Fig. $1 \mathrm{~b}$ ). The optimal time point was $72 \mathrm{~h}$ followed by $48 \mathrm{~h}$ and then $24 \mathrm{~h}$. Moreover, the $\mathrm{IC}_{50}$ values for glufosfamide were significantly lower by about 16,33 , and $48 \%$ compared to ifosfamide at 24,48 , and $72 \mathrm{~h}$, respectively (Table 1 and Fig. $1 \mathrm{a}-\mathrm{c}$ ).

\section{Effects of glufosfamide or ifosfamide on the frequency of apoptosis following Annexin V FITC/PI double stain} Glufosfamide induced apoptosis as shown by the cells that stained positive for Annexin V FITC/Pl (Fig. 2a). The frequency of apoptosis following challenge of HepG2 cells with glufosfamide at concentrations; 10, 25, and $50 \mu \mathrm{M}$ for $48 \mathrm{~h}$ increased by 252,487 , and $1058 \%$ respectively, compared to non-treated cells (Table 2 and Fig. 2c). Likewise, ifosfamide induced apparent positive staining of HepG2 cells following incubation for $48 \mathrm{~h}$ (Fig. 2b). Ifosfamide increased the percent apoptosis by

Table 1 Mean $I C_{50}$ values for glufosfamide or ifosfamide in HepG2 cells following different incubation time periods

\begin{tabular}{lll}
\hline Incubation time & \multicolumn{1}{l}{ HepG2 Cells } \\
\cline { 2 - 3 } & Glufosfamide & Ifosfamide \\
\hline $\mathbf{2 4} \mathbf{~ h}$ & $112.32^{*, a} \pm 8.5$ & $133.0^{*}, \mathrm{~b} \pm 8.9$ \\
$\mathbf{4 8} \mathbf{~ h}$ & $83.23^{*}, \mathrm{a} \pm 5.6$ & $125.0^{*}, \mathrm{~b} \pm 11.2$ \\
$\mathbf{7 2} \mathbf{~ h}$ & $51.66^{*, a} \pm 3.2$ & $100.20^{*}, \mathrm{~b} \pm 7.6$ \\
\hline
\end{tabular}

Data represent mean $\pm \mathrm{SE}, n=6$ (Each concentration was processed in triplicate; each experiment was done twice)

IC50 values were in $\mu \mathrm{M}$

Each drug was added to culture medium at concentration range; $10-1000 \mu \mathrm{M}$ HepG2 cells were seeded at $5000-10,000$ cells per well Cytotoxicity was assessed using MTT assay

* Data in rows having the same superscript are significantly different from each other at $P<0.05$ using independent two-tailed Student's $t$ test

$\mathrm{a}, \mathrm{b}$ Data in columns having the same superscript are significantly different from each other at $P<0.05$ using one way analysis of variance (ANOVA) followed by Tukey as post hoc test 

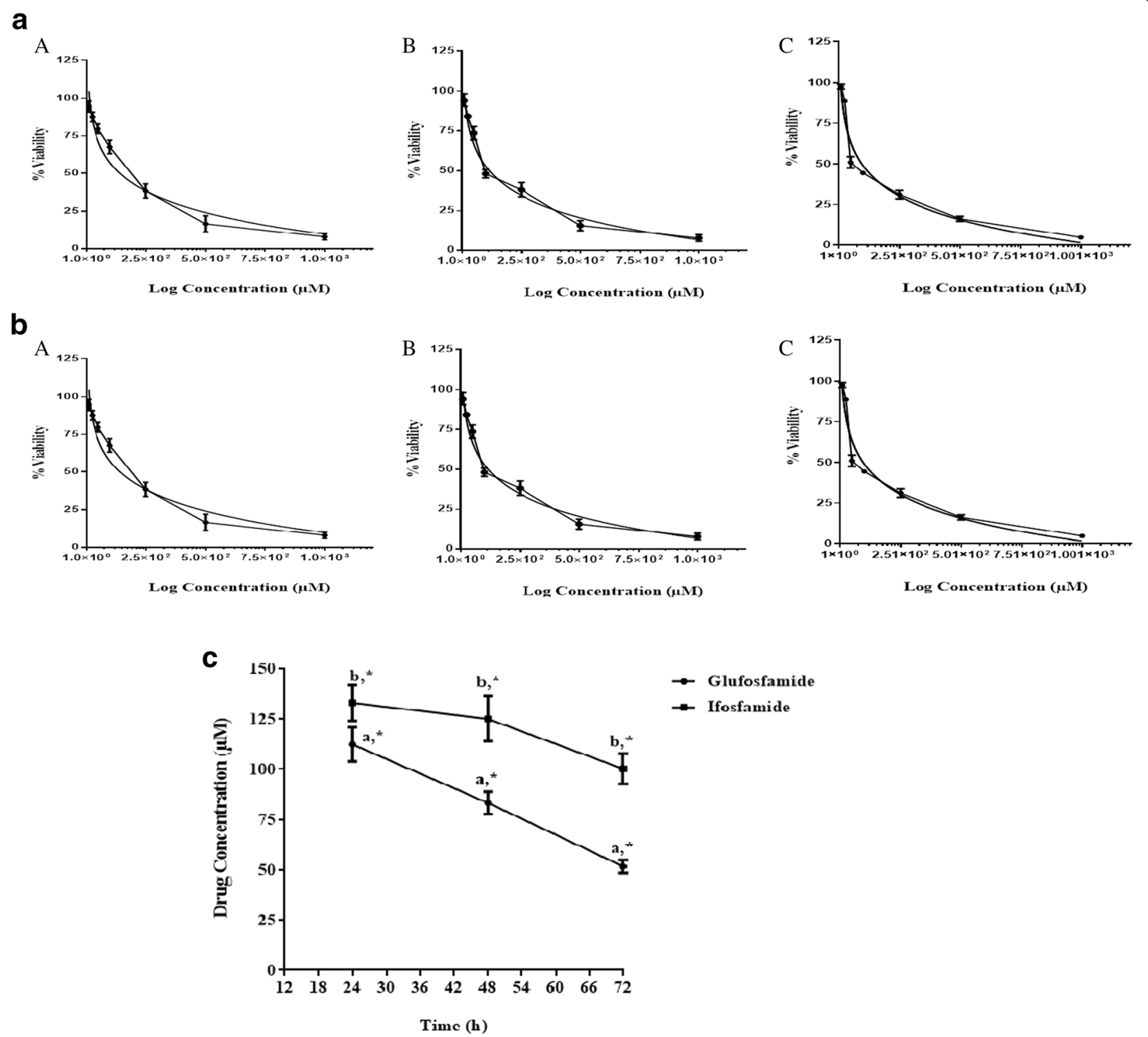

Fig. 1 Concentration response curves and Mean IC50 values of glufosfamide and ifosfamide on HepG2 cells. a Concentration response curves testing the effect of glufosfamide on HepG2 cells at different times $\mathbf{A} 24 \mathrm{~h}, \mathbf{B} 48$ h, and $\mathbf{C} 72 \mathrm{~h}$. b Concentration response curves testing the effect of ifosfamide on HepG2 cells at different times A 24 h, B 48 h, and C 72 h. c Mean IC50 values for glufosfamide and ifosfamide at various time intervals

about 165,362 , and $500 \%$ when used at concentrations; 25,50 , and $100 \mu \mathrm{M}$, respectively, compared to nontreated control cells (Table 3 and Fig. 2c). It was apparent that the frequency of apoptosis following incubation with HepG2 cells for $48 \mathrm{~h}$ was much higher in case of glufosfamide compared to ifosfamide. For instance, the $\mathrm{IC}_{50}$ of glufosfamide $(50 \mu \mathrm{M})$ had higher apoptosis frequency amounted to $93 \%$ compared to the corresponding $\mathrm{IC}_{50}$ of ifosfamide $(100 \mu \mathrm{M})$ (Fig. 2c). Furthermore, glufosfamide increased the incidence of apoptosis by 434, 689, and $1237 \%$ following incubation with HepG2 cells for $72 \mathrm{~h}$ at concentrations; 10,25 , and $50 \mu \mathrm{M}$, respectively, compared to non-treated cells (Table 2 and Fig. 2d). Ifosfamide also increased apoptosis frequency in HepG2 cells when incubated for $72 \mathrm{~h}$ at concentrations 25,50 , and $100 \mu \mathrm{M}$ by 197,380 , and $600 \%$, respectively, compared to non-treated control cells (Table 3 and Fig. 2d). Moreover, the incidence of apoptosis following incubation with HepG2 cells for $72 \mathrm{~h}$ was much higher in case of glufosfamide compared to ifosfamide. For instance, the $\mathrm{IC}_{50}$ of glufosfamide $(50 \mu \mathrm{M})$ provoked higher apoptosis frequency amounted to $91 \%$ compared to the corresponding $\mathrm{IC}_{50}$ of ifosfamide $(100 \mu \mathrm{M})$ (Fig. 2d). Interestingly, incubation of glufosfamide with HepG2 cells for $72 \mathrm{~h}$ 
a

A

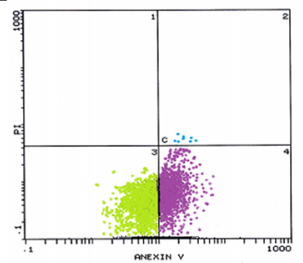

B

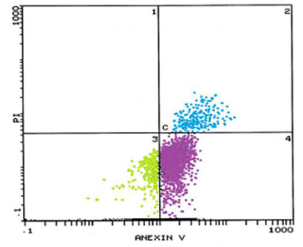

C

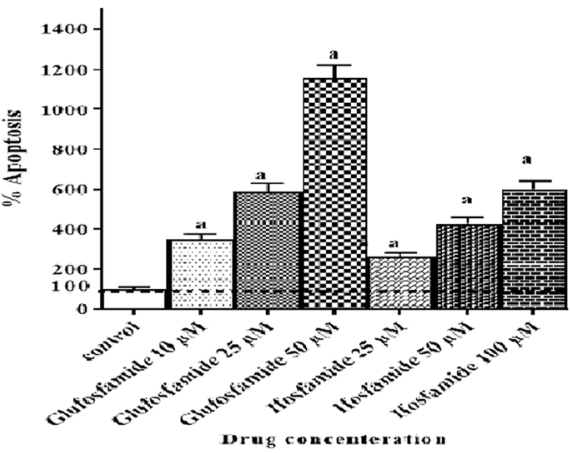

b

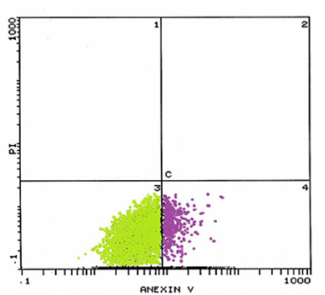

B

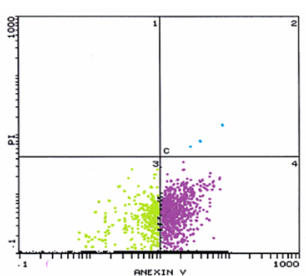

d

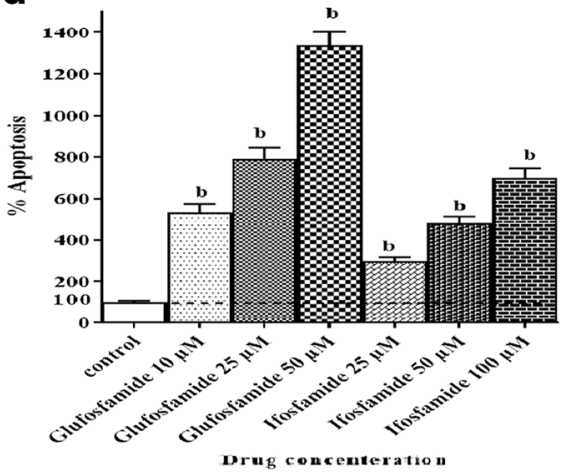

Fig. 2 Effects of glufosfamide or ifosfamide on the frequency of apoptosis following Annexin V FITC/PI double stain. a ANNEXINV FITC/PI apoptosis assay for HepG2 cells after glufosfamide $\mathrm{IC}_{50}(50 \mu \mathrm{M})$ treatment for $\mathbf{A} 48 \mathrm{~h}$ and $\mathbf{B} 72 \mathrm{~h}$. b ANNEXIN V FITC/PI apoptosis assay for HepG 2 cells after ifosfamide IC50 (100 $\mu \mathrm{M})$ treatment for $\mathbf{A} 48 \mathrm{~h}$ and $\mathbf{B} 72 \mathrm{~h}$. c Comparative effects of glufosfamide or ifosfamide on the frequency of apoptosis in HepG2 cells following incubation for $48 \mathrm{~h}$ using Annexin V FITC/PI double stain. $\mathbf{d}$ Comparative effects of glufosfamide or ifosfamide on the frequency of apoptosis in HepG2 cells following incubation for $72 \mathrm{~h}$ using Annexin V FITC/PI double stain

Table 2 Effects of glufosfamide on the frequency of apoptosis in HepG2 cells

\begin{tabular}{lllll}
\hline Time period & Control & \multicolumn{4}{l}{ Glufosfamide $(\boldsymbol{\mu M})^{\mathbf{1}}$} \\
\cline { 3 - 5 } & & $\mathbf{1 0}$ & $\mathbf{2 5}$ & $\mathbf{5 0}$ \\
\hline $48 \mathrm{~h}$ & $3.1 \pm 0.1^{\mathrm{a}}$ & $10.9^{\mathrm{a}} \pm 0.9$ & $18.2^{\mathrm{a}} \pm 1.2$ & $35.9^{\mathrm{a}} \pm 2.1$ \\
$72 \mathrm{~h}$ & $3.5 \pm 0.9^{\mathrm{b}}$ & $18.7^{*}, \mathrm{~b} \pm 1.5$ & $27.6^{*}, \mathrm{~b} \pm 1.7$ & $46.8^{*}, \mathrm{~b} \pm 2.5$ \\
\hline
\end{tabular}

Data represent mean $\pm \mathrm{SE}, n=3$

${ }^{1}$ Glufosfamide was used in its IC50 value beside two of its fractions; 10 and $25 \mu \mathrm{M}$

The number of HepG2 cells used was in the range of $5 \times 105 \sim 5 \times 106$ cells $/ \mathrm{mL}$ Percent apoptosis was calculated as the sum of frequencies of cells in late apoptosis and those undergoing apoptosis

* Significantly different from the same concentration incubated with HepG2 cells for $48 \mathrm{~h}$ at $P<0.05$, using independent two-tailed Student's $t$ test

$a, b$ Data in the same rows having the same superscript are significantly different from each other at $P<0.05$ using one-way analysis of variance (ANOVA) followed by Tukey as post hoc test exhibited higher apoptosis frequencies than those

Table 3 Effects of ifosfamide on the frequency of apoptosis in HepG2 cells

\begin{tabular}{lllll}
\hline Time period & Control & \multicolumn{4}{l}{ Ifosfamide $(\boldsymbol{\mu M})^{\mathbf{1}}$} \\
\cline { 3 - 5 } & & $\mathbf{2 5}$ & $\mathbf{5 0}$ & $\mathbf{1 0 0}$ \\
\hline $\mathbf{4 8 ~ \mathbf { ~ }}$ & $3.1 \pm 0.1^{\mathrm{a}}$ & $8.2^{\mathrm{a}} \pm 0.9$ & $13.2^{\mathrm{a}} \pm 1.1$ & $18.6^{\mathrm{a}} \pm 1.5$ \\
$\mathbf{7 2} \mathbf{~ h}$ & $3.5 \pm 0.9^{\mathrm{b}}$ & $10.4^{*}, \mathrm{~b} \pm 0.6$ & $16.8^{*}, \mathrm{~b} \pm 1.3$ & $24.5^{*, \mathrm{~b}} \pm 2.1$ \\
\hline
\end{tabular}

Data represent mean $\pm \mathrm{SE}, n=3$

1 Ifosfamide was used in its IC50 value beside two of its fractions; 25 and $50 \mu \mathrm{M}$ The number of HepG2 cells used was in the range of $5 \times 10^{5} \sim 5 \times 10^{6}$ cells $/ \mathrm{mL}$ Percent apoptosis was calculated as the sum of frequencies of cells in late apoptosis and those undergoing apoptosis

* Significantly different from the same concentration incubated with HepG2 cells for $48 \mathrm{~h}$ at $P<0.05$, using independent Student's $t$ test

a,b Data in the same rows having the same superscript are significantly different from each other at $P<0.05$ using one-way analysis of variance (ANOVA) followed by Tukey as post hoc test 
observed after $48 \mathrm{~h}$ post-incubation at all concentrations. For instance, the percent apoptosis at $72 \mathrm{~h}$ post-incubation was significantly increased by 72,52 , and $30 \%$ for the concentrations 10,25 , and $50 \mu \mathrm{M}$, respectively, compared the 48-h incubation period for the same concentrations (Table 2). By the same taken, ifosfamide had higher apoptosis frequencies amounted to 27,27 , and $32 \%$ when incubated with the concentrations 25,50 , and $100 \mu \mathrm{M}$ for $72 \mathrm{~h}$ compared to the percent of apoptosis observed

Table 4 Effects of glufosfamide on caspase-9 content in cell lysate of cultured HepG2 cells

\begin{tabular}{|c|c|c|c|c|}
\hline \multirow[t]{2}{*}{ Time period } & \multirow[t]{2}{*}{ Control } & \multicolumn{3}{|c|}{ Glufosfamide $(\mu M) 1$} \\
\hline & & 10 & 25 & 50 \\
\hline $48 \mathrm{~h}$ & $4.0 \pm 0.2^{\mathrm{a}}$ & $15.1^{\mathrm{a}} \pm 1.3$ & $22.5^{\mathrm{a}} \pm 1.2$ & $54.5^{\mathrm{a}} \pm 2.5$ \\
\hline $72 \mathrm{~h}$ & $4.2 \pm 0.5^{b}$ & $23.13^{*, b} \pm 1.9$ & $35.0^{*}, \mathrm{~b} \pm 2.3$ & $72.5^{*, b} \pm 4.1$ \\
\hline
\end{tabular}

Data represent mean $\pm \mathrm{SE}, n=3$

${ }^{1}$ Glufosfamide was used in its $I C_{50}$ value beside two of its fractions; 10 and $25 \mu \mathrm{M}$

The number of HepG2 cells used was in the range of $5 \times 10^{5} \sim 5 \times 10^{6}$ cells $/ \mathrm{mL}$ Caspase- 9 content was expressed as $\mathrm{ng} / \mathrm{mL}$

* Significantly different from the same concentration incubated with HepG2 cells for $48 \mathrm{~h}$ at $P<0.05$, using independent Student's $t$ test

${ }^{a}, \mathrm{~b}$ Data in the same rows having the same superscript are significantly different from each other at $P<0.05$ using one way analysis of variance (ANOVA) followed by Tukey as post hoc test following exposure of HepG2 cells to the same concentrations for only $48 \mathrm{~h}$ (Table 3 ).

\section{Comparative effects of glufosfamide or ifosfamide on caspase- 9 content in HepG 2 cells}

Glufosfamide increased caspase-9 content in HepG2 cells by 278,463 , and $1263 \%$ following incubation with cells for $48 \mathrm{~h}$ at concentrations; 10,25 , and $50 \mu \mathrm{M}$, respectively, compared to non-treated cells (Table 4 and Fig. 3a). Similarly, ifosfamide significantly increased the cellular content of the metalloproteinase by 203,408 , and $673 \%$ at $48 \mathrm{~h}$ post-incubation with 25,50 , and $100 \mu \mathrm{M}$ concentrations, respectively, compared to non-treated control cells (Table 5 and Fig. 3a). Following incubation with HepG2 cells at the concentrations 10,25 , and $50 \mu \mathrm{M}$ of glufosfamide for $72 \mathrm{~h}$, there were increases in the cellular contents of caspase- 9 amounted to 451, 733, and $1626 \%$ compared to non-challenged control cells (Table 4 and Fig. 3b). Likewise, ifosfamide increased caspase-9 content in HepG2 cells by 257, 569, and $870 \%$ following incubation with the drug at concentrations 25,50 , and $100 \mu \mathrm{M}$ for $72 \mathrm{~h}$, respectively, compared to non-treated cells (Table 5 and Fig. $3 \mathrm{~b}$ ). The cellular caspase- 9 levels were significantly higher by 53,56 , and $33 \%$ following incubation of glufosfamide at concentrations; 10,25 , and $50 \mu \mathrm{M}$ for $72 \mathrm{~h}$, respectively,

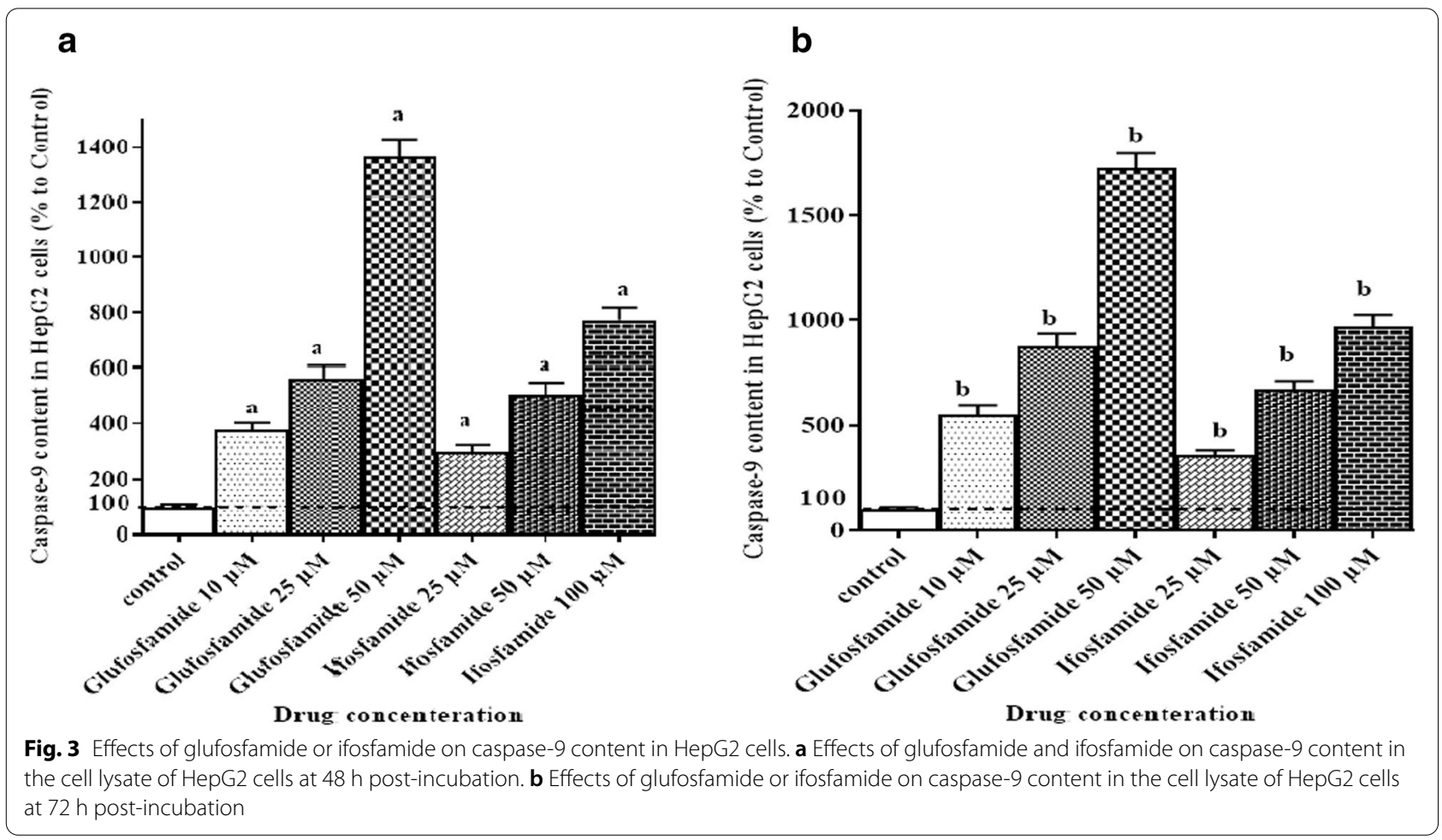


Table 5 Effects of ifosfamide on caspase-9 content in cell lysate of cultured HepG2 cells

\begin{tabular}{lllll}
\hline Time period & Control & \multicolumn{4}{l}{ Ifosfamide $(\boldsymbol{\mu M}) \mathbf{1}$} \\
\cline { 3 - 5 } & & $\mathbf{2 5}$ & $\mathbf{5 0}$ & $\mathbf{1 0 0}$ \\
\hline $\mathbf{4 8} \mathbf{~}$ & $4.0 \pm 0.2^{\mathrm{a}}$ & $12.1^{\mathrm{a}} \pm 0.7$ & $20.3^{\mathrm{a}} \pm 1.4$ & $30.9^{\mathrm{a}} \pm 3.1$ \\
$\mathbf{7 2} \mathbf{~ h}$ & $4.2 \pm 0.5^{\mathrm{b}}$ & $15.0^{*}, \mathrm{~b} \pm 1.3$ & $28.1^{*}, \mathrm{~b} \pm 1.9$ & $40.75^{*}, \mathrm{~b} \pm 2.3$
\end{tabular}

Data represent mean $\pm \mathrm{SE}, n=3$

1 Ifosfamide was used in its IC50 value beside two of its fractions; 25 and $50 \mu \mathrm{M}$ The number of HepG2 cells used was in the range of $5 \times 10^{5} \sim 5 \times 10^{6}$ cells $/ \mathrm{mL}$ Caspase- 9 content was expressed as $\mathrm{ng} / \mathrm{mL}$

* Significantly different from the same concentration incubated with HepG2 cells for $48 \mathrm{~h}$ at $P<0.05$, using independent Student's $t$ test

$a, b$ Data in the same rows having the same superscript are significantly different from each other at $P<0.05$ using one-way analysis of variance (ANOVA) followed by Tukey as post hoc test

compared to the corresponding values following incubation for only $48 \mathrm{~h}$ (Table 4). Ifosfamide also increased caspase- 9 content by about 24,38 , and $32 \%$ when incubated for $72 \mathrm{~h}$ at concentrations; 25, 50, and $100 \mu \mathrm{M}$, respectively, compared to those values obtained with the same concentration regimens at $48 \mathrm{~h}$ post-incubation (Table 5 ).

Notably, the cellular content of caspase- 9 was elevated following exposure to glufosfamide more than ifosfamide. For instance, the $\mathrm{IC}_{50}$ value of glufosfamide $(50 \mu \mathrm{M})$ exhibited cellular increases in the metalloproteinase contents amounted to 76 and $78 \%$ following exposure for 48 and $72 \mathrm{~h}$, respectively, compared to the values observed for the $\mathrm{IC}_{50}$ of ifosfamide $(100 \mu \mathrm{M})$ (Tables 4 and 5).
Comparative effects of glufosfamide and ifosfamide on the expression of caspase-3 gene in HepG2 cells using RT-PCR

Glufosfamide upregulated the executioner gene; caspase-3 in a concentration-dependent manner. Exposure of HepG2 cells to glufosfamide at concentrations; 10, 25, and $50 \mu \mathrm{M}$ for $48 \mathrm{~h}$ significantly induced expression of the effector caspase- 3 amounted to more than sevenfold (778\%), ninefold (978\%), and 11 -fold (1189\%), respectively, compared to control untreated cells (Fig. 4a). Likewise, ifosfamide induced the expression of caspase- 3 in a concentration-dependent. Herein, 48-h ifosfamide exposure at concentrations; 25,50 , and $100 \mu \mathrm{M}$ upregulated the expression of caspase- 3 by more than threefold (389\%), fivefold (556\%), and eightfold (844\%), respectively, compared to untreated HepG2 cells (Fig. 4a).

Following 72-h exposure to glufosfamide at concentrations 10,25 , and $50 \mu \mathrm{M}$, there were increases in caspase-3 gene expression amounted to more than eightfold $(811 \%)$, tenfold $(1089 \%)$, and 14 -fold (1456\%), respectively, compared to untreated cells (Fig. 4b). Ifosfamide, on the other hand, upregulated the gene expression of caspase-3 in HepG2 cells following exposure to ifosfamide for $72 \mathrm{~h}$ at concentrations; 25, 50, and $100 \mu \mathrm{M}$ by more than sixfold (689\%), sevenfold (789\%), and ninefold (978\%), respectively, compared to control untreated cells (Fig. 4b).

It was apparent that 72-h exposure was optimal for the expression of caspase- 3 compared to 48 -h period. For instance the $\mathrm{IC}_{50}$ for glufosfamide $(50 \mu \mathrm{M})$ significantly increased the gene expression following 72-h exposure by $21 \%$ compared to 48 -h exposure time (Fig. 4c). However, the $\mathrm{IC}_{50}$ for ifosfamide $(100 \mu \mathrm{M})$ at 72 -h post-incubation had expression profile for caspase-3 gene that did
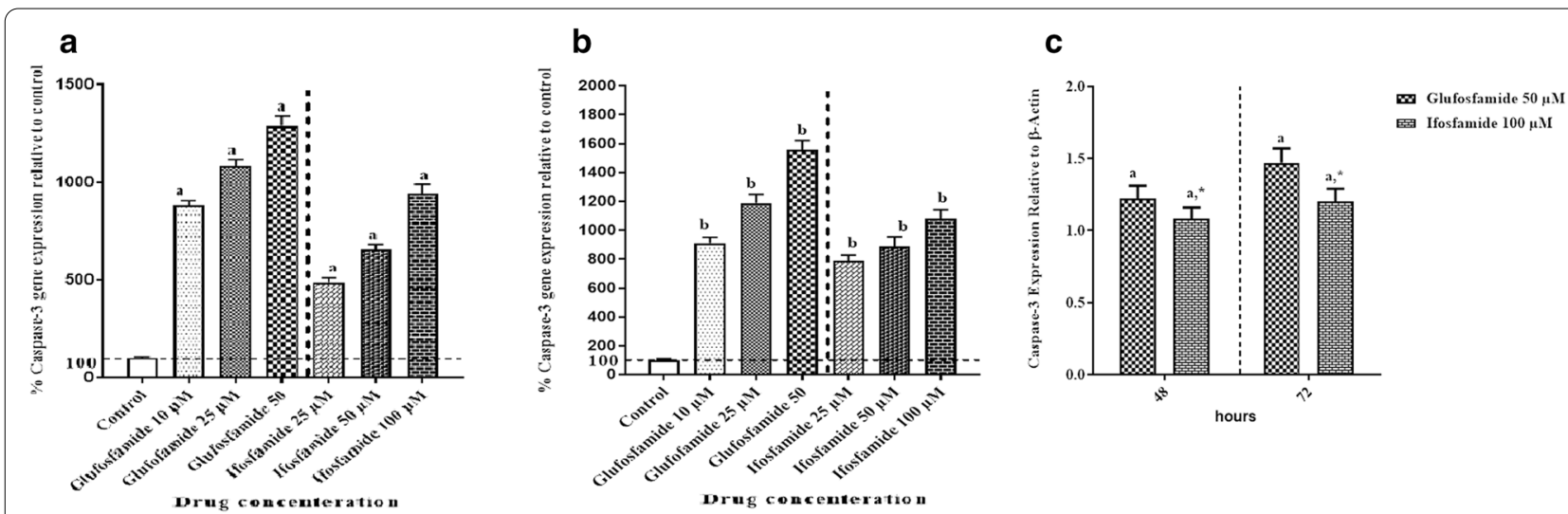

Fig. 4 Effects of glufosfamide and ifosfamide on the expression of caspase-3 gene in HepG2 cells using RT-PCR. a Effects of glufosfamide or ifosfamide on the expression of caspase-3 gene in HepG2 cells at $48 \mathrm{~h}$ post-incubation using RT-PCR. $\mathbf{b}$ Effects of glufosfamide or ifosfamide on the expression of caspase-3 gene in HepG2 cells at $72 \mathrm{~h}$ post-incubation using RT-PCR. c Comparative effects of the IC50 of glufosfamide and ifosfamide on the expression of caspase-3 in HepG2 cells following exposure for 48 and $72 \mathrm{~h}$ 
Table 6 Effects of glufosfamide on $\mathrm{Bcl} 2$ gene expression in HepG2 cells

\begin{tabular}{lllll}
\hline Time period & Control & \multicolumn{4}{l}{ Glufosfamide $(\mu \mathrm{M})^{\mathbf{1}}$} \\
\cline { 3 - 5 } & & $\mathbf{1 0}$ & $\mathbf{2 5}$ & $\mathbf{5 0}$ \\
\hline $\mathbf{4 8} \mathbf{~ h}$ & $2.4 \pm 0.04$ & $1.02^{\mathrm{a}} \pm 0.01$ & $0.9^{\mathrm{a}} \pm 0.02$ & $0.79^{\mathrm{a}} \pm 0.01$ \\
$\mathbf{7 2} \mathbf{~ h}$ & & $0.9^{*}, \mathrm{~b} \pm 0.02$ & $0.73^{*, b} \pm 0.05$ & $0.57^{*}, \mathrm{~b} \pm 0.02$
\end{tabular}

Data represent mean $\pm \mathrm{SE}, n=4$

${ }^{1}$ Glufosfamide was used in its $\mathrm{IC}_{50}$ value beside two of its fractions; 10 and $25 \mu \mathrm{M}$

The number of HepG2 cells used was in the range of $5 \times 10^{5} \sim 5 \times 10^{6}$ cells $/ \mathrm{mL}$ $\mathrm{BCl} 2$ content was normalized to the reference $\beta$-actin gene and expressed as percent expression relative to untreated control cells

* Significantly different from the same concentration incubated with HepG2 cells for $48 \mathrm{~h}$ at $P<0.05$, using independent Student's $t$ test

$\mathrm{a}, \mathrm{b}$ Data in the same rows having the same superscript are significantly different from each other at $P<0.05$ using one-way analysis of variance (ANOVA) followed by Tukey as post hoc test

not differ significantly from that following $48 \mathrm{~h}$ exposure (Fig. 4c).

\section{Comparative effects of glufosfamide and ifosfamide on the gene expression of $\mathrm{Bcl} 2$ in $\mathrm{HepG} 2$ cells}

Glufosfamide decreased the relative expression of the anti-apoptotic Bcl2 gene in HepG2 cells in a concentration-dependent manner. It decreased the expression of the gene by 57,62, and $67 \%$ following exposure of HepG2 cells to concentrations; 10, 25 , and $50 \mu \mathrm{M}$, respectively, for $48 \mathrm{~h}$ compared to untreated control cells (Table 6 and Fig. 5a). At 72-h post-incubation, the decreases in the gene expression were amounted to 62,70 , and $76 \%$ when glufosfamide was used at concentrations; 25, 50, and $100 \mu \mathrm{M}$, respectively, compared to untreated control cells (Table 6 and Fig. 5b). Upon incubation for 48 h, ifosfamide similarly decreased the expression of $\mathrm{Bcl} 2$ in HepG2 cells by 50,59, and $65 \%$ when applied at concentrations; 25,50 , and $100 \mu \mathrm{M}$, respectively, compared to untreated cells (Table 7 and Fig. 5a). On the other hand, 72-h exposure to the same concentrations resulted in gene alterations amounted to 57,64 , and $69 \%$, respectively, compared to control (Table 7 and Fig. 5b). On comparing the effects of either drug on $\mathrm{Bcl} 2$ expression at both time intervals, it was apparent that $72 \mathrm{~h}$ was the optimal exposure time. For instance, the $\mathrm{IC}_{50}$ of glufosfamide $(50 \mu \mathrm{M})$ reduced the gene expression by $28 \%$ compared to the 48 -h time period (Table 6). There was a slight nadir, however, in the expression of $\mathrm{Bcl} 2$ amounted to $12 \%$ compared to the 48-h interval when HepG2 cells were exposed to the $\mathrm{IC}_{50}$ of ifosfamide $(100 \mu \mathrm{M})$ for $72 \mathrm{~h}$ (Table 7$)$.

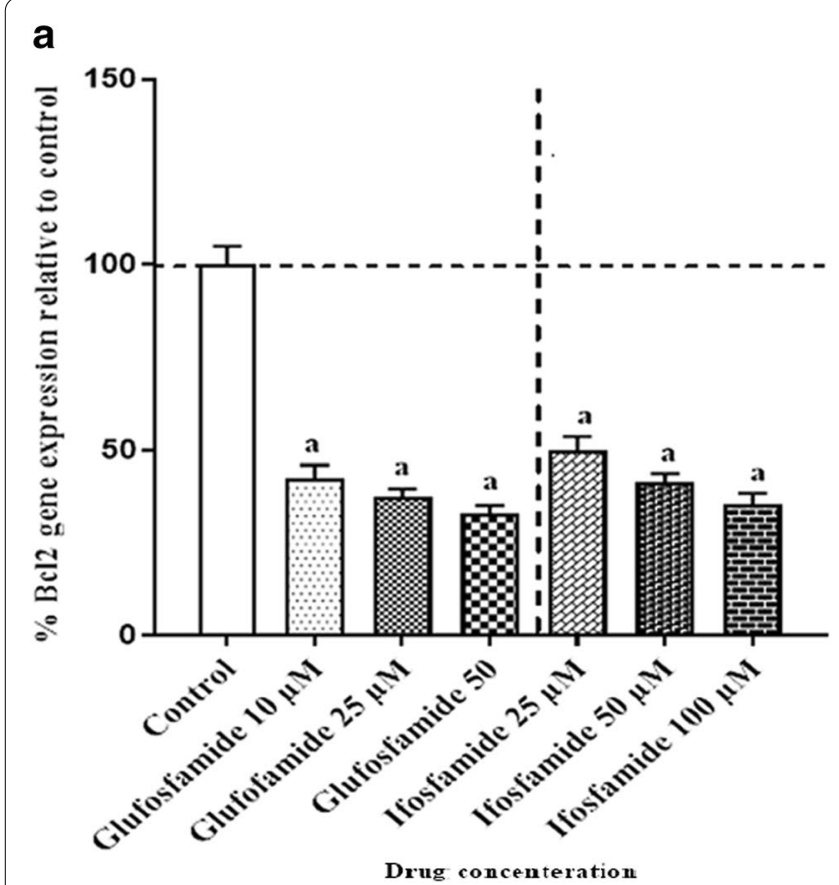

b

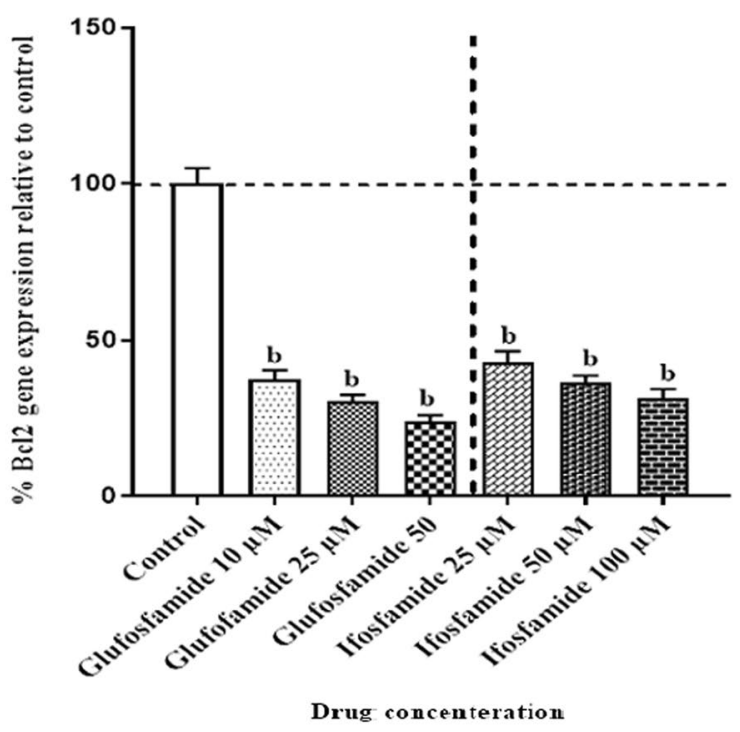

Fig. 5 Effects of glufosfamide and ifosfamide on the gene expression of $\mathrm{Bcl} 2 \mathrm{in} \mathrm{HepG} 2$ cells. a Effects of glufosfamide or ifosfamide on the expression of Bcl2 gene in HepG2 cells at 48 h post-incubation using RT-PCR. $\mathbf{b}$ Effects of glufosfamide or ifosfamide on the expression of Bcl2 gene in HepG2 cells at $72 \mathrm{~h}$ post-incubation using RT-PCR 
Table 7 Effects of ifosfamide on Bcl2 gene expression in HepG2 cells

\begin{tabular}{lllll}
\hline Time period & Control & \multicolumn{4}{l}{ Ifosfamide $(\boldsymbol{\mu M})^{\mathbf{1}}$} \\
\cline { 3 - 5 } & & $\mathbf{2 5}$ & $\mathbf{5 0}$ & $\mathbf{1 0 0}$ \\
\hline $\mathbf{4 8} \mathbf{~}$ & $2.4 \pm 0.04$ & $1.2^{\mathrm{a}} \pm 0.01$ & $0.99^{\mathrm{a}} \pm 0.03$ & $0.85^{\mathrm{a}} \pm 0.02$ \\
$\mathbf{7 2} \mathbf{~ h}$ & & $1.03^{*}, \mathrm{~b} \pm 0.009$ & $0.87^{*}, \mathrm{~b} \pm 0.02$ & $0.75^{*}, \mathrm{~b} \pm 0.01$ \\
\hline
\end{tabular}

Data represent mean $\pm \mathrm{SE}, n=3$

${ }^{1}$ Ifosfamide was used in its $\mathrm{IC}_{50}$ value beside two of its fractions; 25 and $50 \mu \mathrm{M}$ The number of HepG2 cells used was in the range of $5 \times 10^{5} \sim 5 \times 10^{6}$ cells $/ \mathrm{mL}$ $\mathrm{BCl} 2$ content was normalized to the reference $\beta$-actin gene and expressed as percent expression relative to untreated control cells

* Significantly different from the same concentration incubated with HepG2 cells for $48 \mathrm{~h}$ at $P<0.05$, using independent Student's $t$ test

${ }^{a, b}$ Data in the same rows having the same superscript are significantly different from each other at $P<0.05$ using one-way analysis of variance (ANOVA) followed by Tukey as post hoc test

Glufosfamide used at its $\mathrm{IC}_{50}$ also significantly decreased Bcl2 expression by $24 \%$ when applied to culture medium for $72 \mathrm{~h}$ compared to the $\mathrm{IC}_{50}$ of ifosfamide (Tables 6 and 7). There was no significant difference between both glufosfamide and ifosfamide when applied to cultured HepG2 cells for $48 \mathrm{~h}$ at their respective $\mathrm{IC}_{50}$ values (Tables 6 and 7).

\section{Comparative effects of glufosfamide and ifosfamide} on the mitochondrial membrane potential $(\Delta \psi \mathrm{m})$ in HepG2 cells

Glufosfamide significantly lowered the mitochondrial membrane potential in HepG2 cells in a concentration-dependent manner following incubation for $48 \mathrm{~h}$. There were significant decreases in $\Delta \psi \mathrm{m}$ amounted to about 21,32 , and $41 \%$ following exposure to the concentrations; 10,25 , and $50 \mu \mathrm{M}$, respectively, compared to untreated control cells (Fig. 6a). Similar results were observed following 72-h exposure. Glufosfamide used at the same concentration regimens significantly decreased $\Delta \psi \mathrm{m}$ by 30,45 , and $57 \%$, respectively, compared to control cells (Fig. 6b). Likewise, ifosfamide deteriorated the mitochondrial membrane potential in a concentration-dependent manner at either 48 or $72 \mathrm{~h}$. In this sense, following a 48-h exposure, the oxazaphosphorine drug lowered $\Delta \psi \mathrm{m}$ by about 14,30 , and $36 \%$, respectively, when incubated with HepG2 cells at concentrations 25,50 , and $100 \mu \mathrm{M}$, respectively, compared to untreated control cells (Fig. 6a). The detriorations in $\Delta \psi \mathrm{m}$ values after a 72 -h exposure were amounted to 21,33 , and $41 \%$ for the corresponding concentrations; 25, 50, and $100 \mu \mathrm{M}$, respectively, compared to control cells (Fig. 6b). It was obvious that mitochondrial membrane potential was much deteriorated following glufosfamide exposure for $72 \mathrm{~h}$ more than a 48-h exposure. For instance, the $\mathrm{IC}_{50}$ of glufosfamide lowered $\Delta \psi \mathrm{m}$ by $28 \%$ when the cells were incubated with the drug for $72 \mathrm{~h}$ compared to cells treated only for $48 \mathrm{~h}$ (Fig. 6c).

The same holds true for ifosfamide. Exposure of HepG2 cells to the $\operatorname{IC}_{50}(100 \mu \mathrm{M})$ resulted in mitochondrial potential nadir by $9 \%$ compared to the 48 -h exposure period (Fig. 6c).

On comparing the effects of both drugs used at their respective $\mathrm{IC}_{50}$ values, glufosfamide significantly lowered the mitochondrial membrane potential by 8 and $27 \%$ following 48- and 72-h exposure, respectively, compared to ifosfamide-treated HepG2 cells (Fig. 6c).

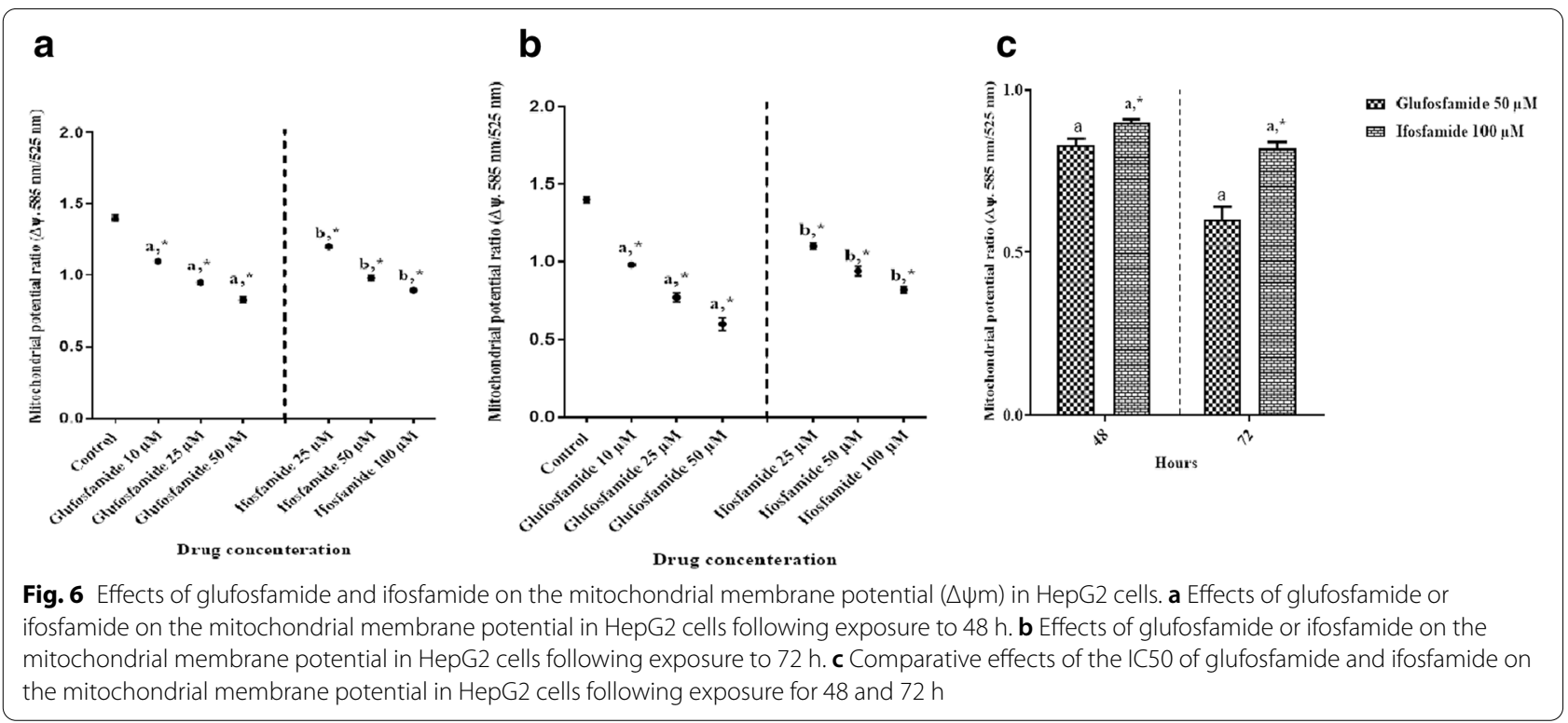




\section{Comparative effects of glufosfamide and ifosfamide on ATP level in HepG2 cells}

Glufosfamide altered ATP level in HepG2 cells in a concentration- and time-dependent manner. The cellular ATP levels were lowered by 21, 37, and 50\% following exposure of HepG2 cells for $48 \mathrm{~h}$ to the concentrations: 10,25 , and $50 \mu \mathrm{M}$, respectively, compared to untreated control cells (Table 8 and Fig. 7a). At 72-h post-incubation, the same concentration regimens of glufosfamide exhibited notable decreases in cellular ATP levels amounted to 27,51 , and $67 \%$, respectively; compared to control HepG2 cells (Table 8 and Fig. 7b). Likewise, ifosfamide reduced cellular ATP levels following exposure of HepG2 cells for $48 \mathrm{~h}$ at 50 and $100 \mu \mathrm{M}$ by 23 and $44 \%$, respectively, compared to non-treated control cells (Table 9 and Fig. 7a). The

Table 8 Effects of glufosfamide on ATP level in HepG2 cells

\begin{tabular}{lllll}
\hline Time period & Control & \multicolumn{2}{l}{ Glufosfamide $(\mu \mathrm{M})^{\mathbf{1}}$} & \\
& & $\mathbf{1 0}$ & $\mathbf{2 5}$ & $\mathbf{5 0}$ \\
\hline $\mathbf{4 8} \mathbf{~ h}$ & $20.9 \pm 1.2$ & $16.6^{\mathrm{a}} \pm 0.9$ & $13.1^{\mathrm{a}} \pm 0.5$ & $9.6^{\mathrm{a}} \pm 0.4$ \\
$\mathbf{7 2} \mathbf{~ h}$ & & $15.3^{\mathrm{b}} \pm 0.6$ & $10.2^{*}, \mathrm{~b} \pm 0.4$ & $6.9^{*}, \mathrm{~b} \pm 0.5$ \\
\hline
\end{tabular}

Data represent mean $\pm \operatorname{SE}(n=4)$

ATP level is expressed as $\mathrm{nmol} / \mathrm{mg}$ protein

${ }^{1}$ Glufosfamide was used in its $\mathrm{IC}_{50}$ value beside two of its fractions; 10 and $25 \mu \mathrm{M}$

The number of HepG2 cells used was in the range of $5 \times 10^{5} \sim 5 \times 10^{6}$ cells $/ \mathrm{mL}$

* Significantly different from the same concentration incubated with HepG2 cells for $48 \mathrm{~h}$ at $P<0.05$, using independent Student's $t$ test

$\mathrm{a}, \mathrm{b}$ Data in the same rows having the same superscript are significantly different from each other at $P<0.05$ using one-way analysis of variance (ANOVA) followed by Tukey as post hoc test
Table 9 Effects of ifosfamide on ATP level in HepG2 cells

\begin{tabular}{lllll}
\hline Time period & Control & \multicolumn{4}{l}{ Ifosfamide $(\boldsymbol{\mu M}) \mathbf{1}$} \\
\cline { 3 - 5 } & & $\mathbf{2 5}$ & $\mathbf{5 0}$ & $\mathbf{1 0 0}$ \\
\hline $\mathbf{4 8} \mathbf{~ h}$ & $20.9 \pm 1.2$ & $19.3 \pm 0.9$ & $15.2^{\mathrm{a}} \pm 0.4$ & $11.6^{\mathrm{a}} \pm 0.5$ \\
$\mathbf{7 2} \mathbf{~ h}$ & & $16.2^{*, b} \pm 0.5$ & $12.1^{*}, \mathrm{~b} \pm 0.3$ & $8.5^{*, \mathrm{~b}} \pm 0.4$ \\
\hline
\end{tabular}

Data represent mean $\pm \mathrm{SE}(n=4)$

ATP level is expressed as $\mathrm{nmol} / \mathrm{mg}$ protein

${ }^{1}$ Ifosfamide was used in its $\mathrm{IC}_{50}$ value beside two of its fractions; 25 and $50 \mu \mathrm{M}$ The number of HepG2 cells used was in the range of $5 \times 10^{5} \sim 5 \times 10^{6}$ cells $/ \mathrm{mL}$

" Significantly different from the same concentration incubated with HepG2 cells for $48 \mathrm{~h}$ at $P<0.05$, using independent Student's $t$ test

${ }^{a, b}$ Data in the same rows having the same superscript are significantly different from each other at $P<0.05$ using one-way analysis of variance (ANOVA) followed by Tukey as post hoc test

lowest concentration had, however, no effect on ATP level. Following exposure to the same concentrations, cellular alterations in ATP levels were amounted to 22, 42 , and $59 \%$, respectively, compared to non-treated HepG2 cells (Table 9 and Fig. 7b).

There was also a notable deterioration in cellular ATP level following exposure to glufosfamide particularly at the $\mathrm{IC}_{50}(50 \mu \mathrm{M})$ for $72 \mathrm{~h}$ amounted to about $28 \% \mathrm{com}$ pared to the 48-h time period. Similarly, exposure of HepG2 cells to the $\mathrm{IC}_{50}$ of ifosfamide $(100 \mu \mathrm{M})$ for $72 \mathrm{~h}$ resulted in a significant reduction in cellular ATP level amounted to $27 \%$ compared to 48 -h exposure (Tables 8 and 9). Further, the cellular ATP levels following exposure to glufosfamide particularly the $\mathrm{IC}_{50}(50 \mu \mathrm{M})$ at 48 - and 72 -h interval were lowered by 17 and $19 \%$, respectively, compared to ifosfamide-challenged cells at the corresponding time intervals (Tables 8 and 9).

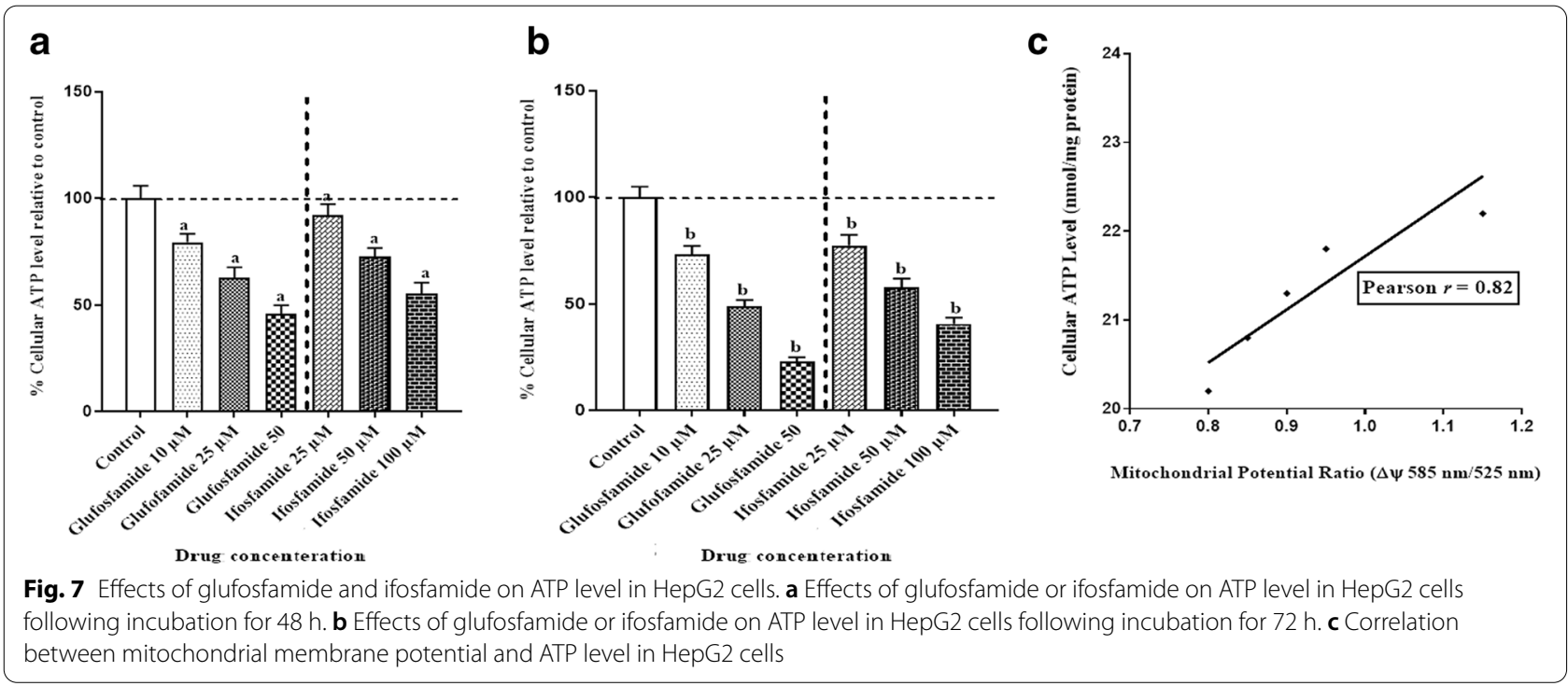


Interestingly, there was a positive correlation between mitochondrial membrane potential and cellular level of ATP in HepG2 cells with a Pearson correlation of $r^{2}$ of about 0.82 (Fig. 7c).

\section{Discussion}

The lack of tumor selectivity of anticancer drugs and the development of multidrug resistance have given impetus to the development of target-specific new cytotoxic compounds, in addition to modification of the targeted drug system to prolong the half-life of the therapeutic targeted system by conjugation as recently published [14].

Amongst the cancer drug targeting modalities recently developed is the concept of saccharides/anti-tumor conjugates; glycoconjugates, the anti-tumor drugs with specific glucose transporters, which transfer the drugs to the tumor cells, where they are selectively up taken and, thus, minimizing the organ toxicity of these compounds and maximizing their pharmacokinetic parameters, thereby reducing the administered doses of the glycodrugs [15].

The cytotoxicity of glufosfamide, let for its parent compound; ifosfamide in hepatocellular carcinoma has never been tested before. Taken together, the current study has been conducted in an attempt to address the possible cytotoxicity of glufosfamide in an in vitro liver tumor paradigm namely; HepG2 cells, in comparison to the parent compound; ifosfamide. Many facets of apoptosis pathway have been unraveled in the present study as a plausible mechanism for the oncolytic activity of both oxazaphosphorine drugs under investigation. The effects of both oxazaphosphorine drugs on mitochondrial membrane potential and consequent energy production have also been investigated.

Apparently, glufosfamide induced cytotoxicity in HepG2 cells in a concentration- and time-dependent manner with the optimal time for cell kill being at $72 \mathrm{~h}$ post-incubation. The same holds true for its aglycone; ifosfamide, yet the $\mathrm{IC}_{50}$ values were notably higher than glufosfamide. Indeed, these results are the first reported data for the cytotoxicity of any oxazaphosphorine drugs in HepG2 cells. The data is consistent with a study of other glucose conjugated drug adriamycin conjugated with 2-amino-2-deoxy-D-glucose and succinic acid (2DG-SUC-ADM) that induced a higher apoptosis than the free drug ADM [16]. The observed cytotoxicity in the current study is in line with previous reported preclinical data in other cancer cell lines $[4,17]$.

The mechanisms underlying glufosfamide cytotoxicity in the current study reside for the most part on the observed apoptotic effects. The tumor cell killing and apoptosis-inducing effects of glufosfamide as one of the oxazaphosphorines are resulted from DNA crosslink formation through covalent bonding of highly reactive alkyl groups of the alkylating nitrogen mustards, resulting from oxazaphosphorines with specific nucleophilic groups of DNA molecules. Oxazaphosphorine-induced apoptosis is always mediated by the mitochondrial pathway, leading to activation of the initiator caspase- 9 which in turn activates the effector caspases- 3 and caspase-7 [18]. In comparison to ifosfamide, the apoptotic effcts of glufosfamide were more profound and this is in harmony with their cytotoxic potentials. Herein, glufosfamide increased the positive annexin $\mathrm{v}$-stained cells, increased caspase-9 cellular content, and upregulated the expression of caspase- 3 gene and meanwhile downregulated Bcl2 gene expression.

Similar apoptotic effects were reported for glufosfamide and other oxazaphosphorines as addressed by various apoptotic assays such as the annexin $\mathrm{v}$ stain, caspases, and Bcl2. A strong decline in the level of Bcl-2 protein and activation of caspase- 3 , caspase- 8 , and caspase-9 were observed in an isogenic variant (CL-V5B) of the Chinese hamster V79 cells following incubation with glufosfamide. Apoptosis increased in a dose-dependent manner and was accompanied by induction of DNA double-strand breaks in the sensitive cells [17]. Another study determined that an enhancement of PC (prostate cancer) cells apoptosis by annexin $\mathrm{v}$ stain following glufosfamide treatment either in single or docetaxel combination drug treatment [19].

Indeed, the mechanisms of apoptosis are highly complex and sophisticated, involving an energy-dependent cascade of molecular events [20]. Irrespective of the exact mechanism involved, caspases are widely expressed in an inactive pro-enzyme form in most cells and once activated can often activate other pro-caspases, allowing initiation of a protease cascade. Some pro-caspases can also be aggregated and autoactivated. This proteolytic cascade, in which one caspase can activate other caspases, amplify the apoptotic signaling pathway, and thus lead to rapid cell death.

One of the biochemical features of apoptosis is the expression of cell surface markers that result in the early phagocytic recognition of apoptotic cells by adjacent cells, permitting quick phagocytosis with minimal compromise to the surrounding tissue. This is achieved by the movement of the normal inward-facing phosphatidylserine of the cell's lipid bilayer to expression on the outer layers of the plasma membrane [21].

In the current study, caspase-9 was elevated in HepG2 cells following exposure to the oxazaphosphorine drugs. Likewise, caspase-3 was upregulated while $\mathrm{Bcl} 2$ was downregulated. In this sense, it is well known that once initiated, caspase- 9 goes on to cleave procaspase- 3 and procaspase-7, which cleave several cellular targets, including poly ADP ribose polymerase. Execution 
caspases activate cytoplasmic endonuclease, which degrades nuclear material, and proteases that degrade the nuclear and cytoskeletal proteins. Caspase-3, caspase-6, and caspase-7 function as effectors or "executioner" caspases, cleaving various substrates including cytokeratins, PARP, the plasma membrane cytoskeletal protein alpha fodrin, the nuclear protein NuMA, and others, that ultimately cause the morphological and biochemical changes seen in apoptotic cells [22].

Caspase- 3 is considered to be the most important of the executioner caspases and is activated by any of the initiator caspases (caspase-8, caspase-9, or caspase-10). In brief, cytochrome c released during apoptosis binds to the adaptor molecule Apaf-1 and leads to the activation of caspase- 9 through the formation of the multimeric apoptosome complex [23]. Caspase-9 then activates the central caspase in the apoptotic signaling machinery, caspase-3. Once caspase-3 is in action, apoptotic cell death is inevitable. The control and regulation of these apoptotic mitochondrial events occur through members of the Bcl-2 family of proteins [24]. It is thought that the main mechanism of action of the Bcl-2 family of proteins is the control of cytochrome $\mathrm{c}$ release from the mitochondria via regulation of mitochondrial membrane permeability. The Bcl-2 family of proteins governs mitochondrial membrane permeability and can be either pro-apoptotic or anti-apoptotic. Previous report indicated that Bcl-2 and $\mathrm{Bcl}-\mathrm{XL}$ inhibit apoptotic death primarily by controlling the activation of caspase proteases [25].

To weld things together, one could speculate that glufosfamide and its parent compound; ifosfamide induced apoptosis in HepG2 cells through activation of the initiator caspase- 9 that in turn activated the executioner caspase- 3 that in association with the downregulation of the anti-apoptotic Bcl2 resulted in a cascade of apoptotic events that ultimately resulted in the observed programmed cell death in the current study. Of major interest was the finding in the present work that glufosfamide and ifosfamide deteriorated the mitochondrial membrane potential alongside with reduced cellular ATP production. It has been documented that maintenance of the mitochondrial membrane potential is critical for ATP synthesis [26].

An earlier study reported that chloroacetaldehyde, the metabolite of ifosfamide, collapsed the mitochondrial membrane potential of osteosarcoma Saos-2 cells, induced the release of cytochrome $\mathrm{c}$ from mitochondria to the cytosol, and significantly reduced cellular ATP levels during the course of death [27].

To explain the exact link between apoptosis and mitochondrial membrane potential, Ly et al. [28] adopted the following scenario. Early in apoptosis, the cells round up, losing contact with their neighbors and shrink. In the cytoplasm, the endoplasmic reticulum dilates and the cisternae swell to form vesicles and vacuoles. In the nucleus, chromatin condenses and aggregates into dense compact masses and is fragmented by endonucleases. The nucleus becomes convoluted and buds off into several fragments, which are encapsulated within the forming apoptotic bodies. In the plasma membrane, cell junctions are disintegrated, whereby the plasma membrane becomes active and convoluted, eventually blebbing. The cell breaks up in a florid manner leading to the "falling away" of several membrane spheres containing the "packaged" cellular contents identified as apoptotic bodies of various sizes.

It remains uncertain whether the loss of $\Delta \psi \mathrm{m}$ occurs as an initiator, or as an effect of apoptosis, or whether it is actually necessary for apoptosis induction to occur. Changes in $\Delta \psi \mathrm{m}$ have been originally postulated to be early and obligate events in the apoptotic signaling pathway. Multiple lines of research demonstrate that the nuclear features of apoptosis are preceded by changes in mitochondrial structure and $\Delta \psi \mathrm{m}$ in some regimes of induction of apoptosis [29]. Whether such $\Delta \psi \mathrm{m}$ deterioration is a first event prior to caspase activation or a sequel thereof, it is quite believed that caspase activation may provide a feedback amplification loop leading to dissipation of $\Delta \psi \mathrm{m}[28]$.

The previous report by Harris and Thompson (30) showed that Bcl-2 family proteins have been hypothesized to coordinate the permeability of both the outer and inner mitochondrial membranes through the permeability transition $(\mathrm{PT})$ pore may lend support to this view. By regulating mitochondrial membrane physiology, $\mathrm{Bcl}-2$ proteins also affect mitochondrial energy generation and thus influence cellular bioenergetics. Thereby, there was no wonder that by decreasing the mitochondrial membrane potential along with the downregulation of $\mathrm{Bcl} 2$ gene, glufosfamide, and its aglycone reduced ATP production in HepG2 cells. Hence, one could argue that the cytotoxicity of both oxazaphosphorine drugs observed in HepG2 cells may be ascribed to not just apoptotic signaling but presumably to alteration of energy production as well secondary to the deterioration of mitochondrial membrane potential.

\section{Conclusions}

In conclusion, from the obtained data it is concluded that when well analyzed, the current study reported for the first time cytotoxicity activity of glufosfamide in hepatocellular carcinoma in vitro; namely, HepG2 cells relative to its parent aglycan ifosfamide. Glufosfamide showed a higher oncolytic activity in HepG2 cells than ifosfamide that was confirmed through MTT cytotoxic assay, flowcytometric analysis of apoptosis frequencies using Annexin V/PI double stain, and measurement of 
apoptotic markers (caspase-9, caspase-3, and Bcl2 gene expression) by immunocytochemical assay and real-time PCR. This in addition to shedding more light about the mechanism of apoptosis through measurement of mitochondrial membrane potential by the potentiometric dye; JC-1 and ATP production measured by the luciferasechemiluminescence technique. The generated data warrants further elucidations by in vivo study.

\begin{abstract}
Abbreviations
HCC: Hepatocellular carcinoma; HepG2: Human hepatoma cell line; IFO: Ifosfamide; GLU: Glufosfamide; Real time-PCR: Real-time polymerase chain reaction; LRU: Luminescence relative units; CPS: Count per second; ATP: Adenosine triphosphate; IC50: Half maximal inhibitory concentration.
\end{abstract}

\section{Acknowledgements}

We are indebted to Dr. Mohamed A. Ragheb (Faculty of Science, Cairo University) for his valuable comments.

\section{Authors' contributions}

DE: conceptualization, methodology, investigation, validation, and software. FB: data curation, writing-original draft preparation, and editing. HK: writingreviewing and editing. AS: supervision. HM: supervision, conceptualization, investigation, data curation, and reviewing. The authors have read and approved the manuscript.

\section{Funding}

This research did not receive any specific grant from funding agencies in the public,

commercial, or not-for-profit sectors.

\section{Availability of data and materials}

All data and materials are available upon request.

\section{Declarations}

Ethics approval and consent to participate

Not applicable.

\section{Consent for publication}

Not applicable.

\section{Competing interests}

The authors declare that they have no competing interests.

\section{Author details}

${ }^{1}$ Department of Biochemistry, Misr University for Science \& Technology (MUST), Giza, Egypt. ${ }^{2}$ Biochemistry Lab.Department of Chemistry, Faculty of Science, Cairo University, Giza, Egypt. ${ }^{3}$ Department of Pharmacology and Toxicology, Faculty of Pharmacy Ahram Canadian University, Giza 267119, Egypt.

Received: 15 June 2021 Accepted: 26 July 2021

Published online: 23 August 2021

\section{References}

1. Kew MC. Epidemiology of hepatocellular carcinoma in sub-Saharan Africa. Ann Hepatol. 2013;12(2):173-82.

2. Terada T, Ueda K, Nakanuma Y. Histopathological and morphometric analysis of atypical adenomatous hyperplasia of human cirrhotic livers. Virchows Arch A Pathol Anat Histopathol. 1993;422(5):381-8.

3. Hanahan D, Weinberg RA. The hallmarks of cancer. Cell. 2000;100(1):57-70.
4. Pohl J, Bertram B, Hilgard P, Nowrousian MR, Stuben J, Wiessler M. D-19575-a sugar-linked isophosphoramide mustard derivative exploiting transmembrane glucose transport. Cancer Chemother Pharmacol. 1995;35(5):364-70.

5. Mazur L, Opydo-Chanek M, Stojak M. Glufosfamide as a new oxazaphosphorine anticancer agent. Anticancer Drugs. 2011;22(6):488-93.

6. Veyhl M, Wagner K, Volk C, Gorboulev V, Baumgarten K, Weber WM, et al. Transport of the new chemotherapeutic agent beta-D-glucosylisophosphoramide mustard (D-19575) into tumor cells is mediated by the Na+-D-glucose cotransporter SAAT1. Proc Natl Acad Sci U S A. 1998;95(6):2914-9.

7. Stuben J, Port R, Bertram B, Bollow U, Hull WE, Schaper M, et al. Pharmacokinetics and whole-body distribution of the new chemotherapeutic agent beta-D-glucosylisophosphoramide mustard and its effects on the incorporation of [methyl-3H]-thymidine in various tissues of the rat. Cancer Chemother Pharmacol. 1996;38(4):355-65.

8. Knowles BB, Howe CC, Aden DP. Human hepatocellular carcinoma cell lines secrete the major plasma proteins and hepatitis B surface antigen. Science. 1980;209(4455):497-9.

9. Louis KS, Siegel AC. Cell viability analysis using trypan blue: manual and automated methods. Mammalian cell viability: Springer; 2011. 7-12.

10. Mosmann T. Rapid colorimetric assay for cellular growth and survival: application to proliferation and cytotoxicity assays. J Immunol Methods. 1983;65(1):55-63.

11. Chou TC, Talalay P. Quantitative analysis of dose-effect relationships: the combined effects of multiple drugs or enzyme inhibitors. Adv Enzyme Regul. 1984;22:27-55.

12. Cossarizza A, Baccaranicontri M, Kalashnikova G, Franceschi C. A new method for the cytofluorometric analysis of mitochondrial membrane potential using the $\mathrm{J}$-aggregate forming lipophilic cation 5,5',6,6'-tetrachloro-1, 1',3,3'-tetraethylbenzimidazolcarbocyanine lodide (JC-1). Biochem Biophys Res Commun. 1993;197(1):40-5.

13. Mikirova N, Riordan HD, Kirby R, Klykov A, Jackson JA. Monitoring of ATP levels in red blood cells and T cells of healthy and III subjects and the effects of age on mitochondrial potential. Journal of Orthomolecular Medicine. 2004;20:50-8.

14. AlQahtani AD, Al-mansoori L, Bashraheel SS, Rashidi FB, Al-Yafei A, Elsinga $P$, et al. Production of "biobetter" glucarpidase variants to improve drug detoxification and antibody directed enzyme prodrug therapy for cancer treatment. Eur J Pharm Sci. 2019;127:79-91.

15. Molejon MI, Weiz G, Breccia JD, Vaccaro MI. Glycoconjugation: an approach to cancer therapeutics. World journal of clinical oncology. 2020;11(3):110-20.

16. Cao J, Cui S, Li S, Du C, Tian J, Wan S, et al. Targeted cancer therapy with a 2-deoxyglucose-based adriamycin complex. Cancer Res. 2013:73(4):1362-73.

17. Becker R, Ritter A, Eichhorn U, Lips J, Bertram B, Wiessler M, et al. Induction of DNA breaks and apoptosis in crosslink-hypersensitive V79 cells by the cytostatic drug $\beta$-D-glucosyl-ifosfamide mustard. Br J Cancer. 2002;86(1):130-5.

18. Waxman DJ, Schwartz PS. Harnessing apoptosis for improved anticancer gene therapy. Cancer Res. 2003;63(24):8563-72.

19. Attia RT, Tolba MF, Trivedi R, Tadros MG, Arafa HM, Abdel-Naim AB. The chemomodulatory effects of glufosfamide on docetaxel cytotoxicity in prostate cancer cells. PeerJ. 2016;4:e2168.

20. Elmore S. Apoptosis: a review of programmed cell death. Toxicol Pathol. 2007;35(4):495-516.

21. Bratton DL, Fadok VA, Richter DA, Kailey JM, Guthrie LA, Henson PM. Appearance of phosphatidylserine on apoptotic cells requires calciummediated nonspecific flip-flop and is enhanced by loss of the aminophospholipid translocase. J Biol Chem. 1997;272(42):26159-65.

22. Slee EA, Adrain C, Martin SJ. Executioner caspase-3,-6, and-7 perform distinct, non-redundant roles during the demolition phase of apoptosis. J Biol Chem. 2001;276(10):7320-6.

23. Acehan D, Jiang X, Morgan DG, Heuser JE, Wang X, Akey CW. Threedimensional structure of the apoptosome: implications for assembly, procaspase-9 binding, and activation. Mol Cell. 2002;9(2):423-32.

24. Cory S, Adams JM. The Bcl2 family: regulators of the cellular life-or-death switch. Nat Rev Cancer. 2002;2(9):647-56. 
25. Newmeyer DD, Bossy-Wetzel E, Kluck RM, Wolf BB, Beere HM, Green DR. BCl-XL does not inhibit the function of Apaf-1. Cell Death Differ. 2000;7(4):402-7.

26. Papucci L, Schiavone N, Witort E, Donnini M, Lapucci A, Tempestini A, et al. Coenzyme q10 prevents apoptosis by inhibiting mitochondrial depolarization independently of its free radical scavenging property. $J$ Biol Chem. 2003;278(30):28220-8.

27. Takahashi K, Sakurai K, Takahashi K, Tanaka H, Fujimoto Y. Necrotic pathway in human osteosarcoma Saos-2 cell death induced by chloroacetaldehyde. Anticancer Drugs. 2007;18(5):543-53.

28. Ly JD, Grubb DR, Lawen A. The mitochondrial membrane potential $(\Delta \psi \mathrm{m})$ in apoptosis; an update. Apoptosis. 2003;8(2):115-28.

29. Barbu A, Welsh N, Saldeen J. Cytokine-induced apoptosis and necrosis are preceded by disruption of the mitochondrial membrane potential $(\Delta \psi \mathrm{m})$ in pancreatic RINm5F cells: prevention by Bcl-2. Mol Cell Endocrinol. 2002;190(1):75-82.

30. Harris $\mathrm{MH}$, Thompson $\mathrm{CB}$. The role of the $\mathrm{BCl}-2$ family in the regulation of outer mitochondrial membrane permeability. Cell Death Differ. 2000;7(12):1182-91.

\section{Publisher's Note}

Springer Nature remains neutral with regard to jurisdictional claims in published maps and institutional affiliations.

\section{Submit your manuscript to a SpringerOpen ${ }^{\odot}$ journal and benefit from:}

- Convenient online submission

- Rigorous peer review

- Open access: articles freely available online

- High visibility within the field

- Retaining the copyright to your article

Submit your next manuscript at $\boldsymbol{\nabla}$ springeropen.com 